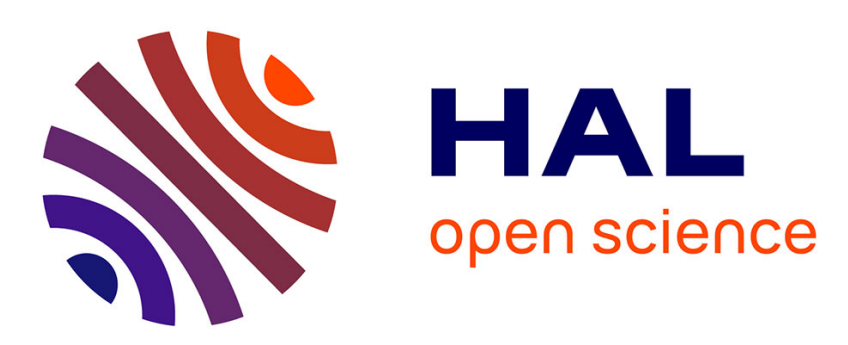

\title{
Evolution of Toxoplasma-PCR methods and practices: a French national survey and proposal for technical guidelines
}

Guillaume Roux, Emmanuelle Varlet-Marie, Patrick Bastien, Yvon Sterkers

\section{- To cite this version:}

Guillaume Roux, Emmanuelle Varlet-Marie, Patrick Bastien, Yvon Sterkers. Evolution of ToxoplasmaPCR methods and practices: a French national survey and proposal for technical guidelines. International Journal for Parasitology, 2018, 48 (9-10), pp.701-707. 10.1016/j.ijpara.2018.03.011 . hal02318790

\section{HAL Id: hal-02318790 \\ https://hal.umontpellier.fr/hal-02318790}

Submitted on 30 Mar 2020

HAL is a multi-disciplinary open access archive for the deposit and dissemination of scientific research documents, whether they are published or not. The documents may come from teaching and research institutions in France or abroad, or from public or private research centers.
L'archive ouverte pluridisciplinaire HAL, est destinée au dépôt et à la diffusion de documents scientifiques de niveau recherche, publiés ou non, émanant des établissements d'enseignement et de recherche français ou étrangers, des laboratoires publics ou privés. 


\section{Evolution of Toxoplasma-PCR methods and practices; a French national survey and proposal for technical guidelines}

Guillaume Roux ${ }^{\mathrm{ac}}$, Emmanuelle Varlet-Marie ${ }^{\mathrm{bc}}$, Patrick Bastien ${ }^{\mathrm{bc}}$ and Yvon Sterkers ${ }^{\mathrm{bc} \# \text {, on }}$ behalf of the French National Reference Center for Toxoplasmosis Network

a Department of Microbiology, University Hospital of Nîmes, Nîmes, France

b Centre Hospitalier Universitaire (CHU) of Montpellier, University of Montpellier, Department of Parasitology-Mycology, Research unit "MiVEGEC" (CNRS 5290/IRD 224/UM), Montpellier, France.

c Molecular Biology 'Pole' of the National Reference Center for Toxoplasmosis, Montpellier, France.

Members of the French National Reference Center for Toxoplasmosis Network : B. CIMON (Angers), I. ACCOCEBERRY and L. DELHAES (Bordeaux), D. QUINIO (Brest), M. VERGNAUD and J. BONHOMME (Caen), M. DEMAR and D. BLANCHET (Cayenne), V. LIVRELLI (ClermontFerrand), F. BOTTEREL-CHARTIER (Créteil), F. DALLE and S. VALOT (Dijon), H. PELLOUX and MP. BRENIER-PINCHART (Grenoble), B. SENDID and E. FRÉALLE (Lille), ML. DARDE and JB. MURAT (Limoges), M. RABODONIRINA and D. DUPONT (Lyon), C. L'OLLIVIER (Marseille), M. MACHOUART and A. DEBOURGOGNE (Nancy), F. MORIO (Nantes), P. MARTY and L. HASSEINE (Nice), S. HOUZE and N. ARGY (Paris-Bichat-Claude-Bernard), H. YERA (Paris-Cochin), L. PARIS and F. TOUAFEK (Paris-Pitié-Salpétrière), C. HENNEQUIN and J. GUITARD (Paris-Saint-Antoine), S. BRETAGNE and J. MENOTTI (Paris-Saint-Louis), E. PERRAUD-CATEAU (Poitiers), I. VILLENA and F. FOUDRINIER (Reims), F. ROBERTGANGNEUX (Rennes), L.FAVENNEC (Rouen), P. FLORI (St-Étienne), E. CANDOLFI, D. FILISETTI and O. VILLARD (Strasbourg), S. CASSAING and J. FILLAUX (Toulouse), N. VANLANGENDONCK (Tours)

Running title: Toxoplasma-PCR methods in France from 2008 to 2015

\# Address correspondence to Yvon Sterkers, Laboratoire de Parasitologie-Mycologie, 39 Avenue Charles Flahault - 34295 Montpellier cedex 5 - France ; yvon.sterkers@umontpellier.fr, phone : +33(0)4 67332350 ; fax : +33 (0)4 67332358

Keywords : Toxoplasma gondii ; PCR ; prenatal diagnosis; technical guidelines

This manuscript has been published, please cite: Evolution of Toxoplasma-PCR methods and practices: a French national survey and proposal for technical guidelines. Roux G, VarletMarie E, Bastien P, Sterkers Y; French National Reference Center for Toxoplasmosis Network. Int J Parasitol. 2018 Aug;48(9-10):701-707. doi: 10.1016/j.ijpara.2018.03.011. Epub 2018 Jun 8. PMID: 29886198 


\title{
Highlights
}

$\checkmark$ Diversity of methods and practices of Toxoplasma-PCR remained at a high level in 2015

$\checkmark$ This diversity hinders inter-laboratory comparisons of performances

$\checkmark$ Knowledge of the most frequent methods used provides elements for technical choices

\begin{abstract}
The molecular diagnosis of toxoplasmosis lacks standardization due to the use of numerous methods with variable performances. This diversity of methods also impairs robust performance comparisons between laboratories. The harmonization of practices by diffusion of technical guidelines is an attractive way to improve these performances. The knowledge of methods and practices used for this molecular diagnosis is an essential step to provide guidelines for Toxoplasma-PCR. In the present study, we aimed (i) to describe the methods and practices of Toxoplasma-PCR used by clinical microbiology laboratories in France and (ii) to propose technical guidelines to improve molecular diagnosis of toxoplasmosis. To do so, a yearly self-administered questionnaire-based survey was undertaken in proficient French laboratories from 2008-2015; and guidelines were proposed based on the results and previous published works. This period saw the progressive abandonment of conventional PCR methods, of Toxoplasma-PCR targeting the B1 gene and of the use of two concomitant molecular methods for this diagnosis. The diversity of practices persisted during the study, in spite of the increasing use of commercial kits such as PCR kits, DNA extraction controls and PCR inhibition controls. We also observed a tendency to the automation of DNA extraction. The evolution of practices did not always go together with an improvement, as reported notably by the declining use of Uracil-DNA Glycosylase to avoid carry-over contamination. We here propose technical recommendations which correspond to items explored during the survey, with respect to DNA extraction, Toxoplasma-PCR and PCR good practices.
\end{abstract}

\section{Introduction}

Toxoplasma gondii infection is a worldwide public health concern, particularly for pregnant women exposing the fetus to a risk of congenital toxoplasmosis and for immunosuppressed patients. Prenatal and post-natal diagnosis of congenital toxoplasmosis relies notably on Toxoplasma-PCR (Pomares and Montoya, 2016). Excellent sensitivity of the PCR is required because the parasite burden is often low, the median parasitic load in amniotic fluid being <10 parasites/mL (Costa et al., 2001). Molecular diagnosis has also become crucial in the diagnosis of toxoplasmosis in immunocompromised patients (Daval et al., 2010; Robert-Gangneux and Belaz, 2016). However, there are no internationally recognized guidelines concerning this molecular diagnosis specifically. Besides, a high diversity of Toxoplasma-PCR methods, most of them being laboratory-developed assays, has been published or marketed, and differences in their performances observed (Cassaing et al., 2006; Kaiser et al., 2007; Bastien et al., 2007). The rationale of the present study is that the knowledge of the diversity and evolution of ToxoplasmaPCR assays permits to propose guidelines and to promote some degree of standardization for this diagnosis. For that purpose, we performed a questionnairebased survey targeting French laboratories performing Toxoplasma-PCR, with two main and three secondary objectives. The general objectives of this study were (i) to describe the evolution of practices from 2008 to 2015, and (ii) to propose Toxoplasma-PCR technical guidelines based on the results of this survey and on 
previously published works. Three secondary objectives concerned the different steps of the molecular diagnosis process. We aimed to explore the evolution of the DNA extraction methods, trend to automation and possible reasons for these changes. We also wished studying the evolution of the PCR targets, PCR primers and amplicon detection techniques. Finally, we wanted to analyze the practices which may improve the quality of Toxoplasma-PCR results, more particularly the number of reaction tubes performed per clinical sample, the DNA extraction control methods and amplification control methods, as well as the mastering of the carry-over contamination risk.

\section{Materials and methods}

\subsection{General description of the survey}

The Department of Parasitology-Mycology of the academic hospital (C.H.U.) of Montpellier is coordinating the Molecular biology 'pole' of the French National Reference Center for Toxoplasmosis (NRC-T, http://cnrtoxoplasmose.chureims.fr) and, as such, has been organizing the national external quality assessment (EQA) for Toxoplasma-PCR since 2002 (Bastien et al., 2007). Participation to this EQA is free and on a voluntary basis, but in return, participating centers are asked to answer a self-administered questionnaire about their methods and practices. The annual questionnaires included queries concerning what we considered as the most critical points of the PCR process (Sterkers et al., 2010b). The answers had to be given considering the routine practice, and not the procedures that might have been performed for the EQA only. The questionnaire comprised 18 items in 2008 and was progressively enriched with 13 more items (see questionnaire in http://dx.doi.org/10.17632/zpjdkh4274.1).

These 13 supplementary items were analyzed separately since they represented a change introduced during the survey.

\subsection{Survey administration}

Promotion of the EQA and the survey was realized during scientific congresses and meetings by NRC-T's members in order to target the whole of French clinical laboratories performing the molecular diagnosis of toxoplasmosis. Participants transmitted their reply by postal mail in 2008 and 2009, by email from 2010 to 2014, and then using an Internet platform with personal login for each laboratory in 2015. Questionnaire notifications with deadline were sent by postal mail to correspondents of each participating laboratories together with the EQA samples. Reminder e-mails were also sent a few days before the deadline. About one month after each session, we performed data managing and preliminary analysis of the annual results. Response rates were calculated by the ratio of the number of laboratories who gave a reply over the number of laboratories who participated to the EQA. We performed a descriptive study with no inference tests since near the whole of the French laboratories practicing Toxoplasma-PCR was sampled. Participating laboratories who transmitted their data to the NRC-T agreed to their use for scientific purpose and no explicit refusal was reported.

\subsection{Guidelines redaction}

Guidelines were written in order to improve performances of ToxoplasmaPCR and are only related to the technical points explored by the survey. The guidelines proposal was supported by the three types of evidence defined by Howick and colleagues (Howick et al., 2009): firstly, direct evidence corresponding to published performance assessment or comparison of methods; secondly, mechanistic evidence supporting causality and the superiority of one method over another one; and thirdly, parallel evidence comprising in particular the replicability of the performance evidences. The possibility to compare practices among 'peer groups', which fits in the third type of evidence, may also help a laboratory to distinguish 
between a specific technical problem and the overall limitation of the method used by this participant.

\section{Results and discussion}

\subsection{General description of the survey}

We analyzed the responses of nearly 30 laboratories every year. Two laboratories dropped out from the survey in 2009 and in 2015, respectively, one because it closed, the second one because it preferred a commercial EQA; and two laboratories joined it in 2010 and in 2012 (http://dx.doi.org/10.17632/zpjdkh4274.1). The global response rate was $95.3 \%$. All participating centers were public laboratories and all but two were in academic hospitals. All clinical microbiology laboratories authorized by French Health authorities for performing the prenatal diagnosis of toxoplasmosis participated to the survey, except two large private laboratories, a fact which constitutes one of the limitations of the study. Also, this survey did not explore detailed protocols in depth; so there may be some additional heterogeneity of practices between laboratories reporting the same method.

\subsection{Evolution of methods and practices and proposed technical guidelines}

The survey analyzed 31 items covering what we considered as critical points of the Toxoplasma-PCR method in routine practice. The knowledge brought by this survey, together with the data already published in the literature, allowed us to propose some technical guidelines, following the methodology proposed by Howick et al. (Howick et al., 2009). Among other criteria, we consider that methods already used by a large number of users are valuable choices per se; in addition, they permit to join a peer group for comparisons.

\subsubsection{DNA extraction methods}

DNA extraction methods evolved slowly toward automation, but diversity was maintained. The most used DNA extraction method during the whole period was a manual one using silica columns (Qiagen ${ }^{\circledR}$ ), although its use decreased over the years, concomitantly to the increased use of automated DNA extraction and to the abandonment of using a second 'confirmation' PCR method (Figure 1.A and 1.B and Table S1). Indeed, from 8/29 laboratories $(27.6 \%)$ in 2008 , the use of a second 'confirmation' method persisted only in $1 / 26$ laboratory (3.8 \%) in 2015 (Figure 1.A). The two methods used in each laboratory were differentiated by the amplification or revelation process, including DNA target, primers, probe(s) or use of agarose gel, in 23/30 cases; the thermal cycler devices in $4 / 30$ cases; and the extraction method in $3 / 30$ cases (for details, see Table S1 and http://dx.doi.org/10.17632/zpjdkh4274.1).

The use of a second molecular diagnostic method had been justified to compensate a low sensitivity of Toxoplasma-PCR methods. Actually, the use of two distinct Toxoplasma-PCR methods in one laboratory is confusing in case of discrepant results between both methods, as this may reflect a better sensitivity/lower specificity or vice-versa. Therefore we do not recommend the use of a second 'confirmation' PCR method. Between 2008 and 2015, the use of automated DNA extraction methods in France increased from $21.6 \%(8 / 37)$ to $44.4 \%(12 / 27)$ (Figure 1.C). This was still far lower than the $90 \%$ extraction automation reported in 2012 in Italian laboratories performing PCR (Tomasoni et al., 2014). The evolution to automation of DNA extraction was more important in centers sharing molecular biology equipment on a technical platform than in others (Figure 1.D). The most popular automated DNA extraction method in 2008 was MagNaPure (Roche $\AA$ ) whereas in 2015 it was easyMAG (Biomérieux ${ }^{\circledR}$ ) (Figure 1.E). The choice of an extraction 
method by laboratories should be guided by its suitability to a PCR assay for optimal performance; but it was probably driven by the need for sharing equipment in microbiology laboratories, as well as cost constraints. We wish to highlight the need for optimization between DNA extraction and amplification method. Indeed, small variations in extraction protocols may influence extraction yields for Toxoplasma-PCR in the case of low parasitic loads, even using automates (Yera et al., 2009; Faucher et al., 2012), making

A

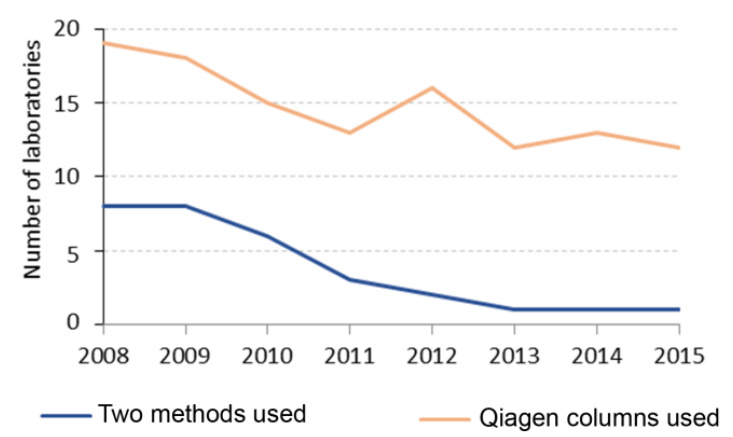

C

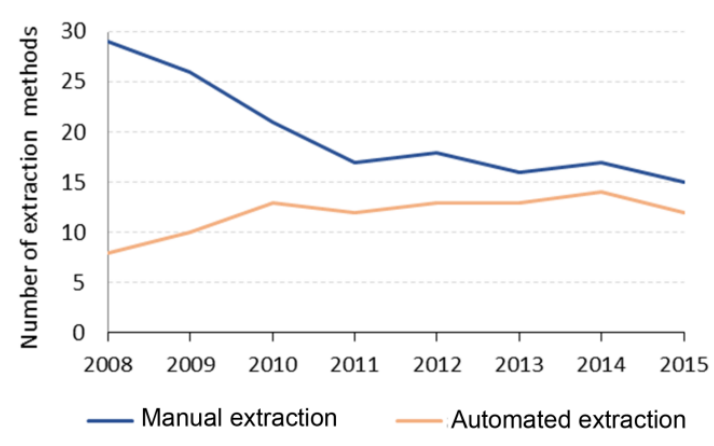

E

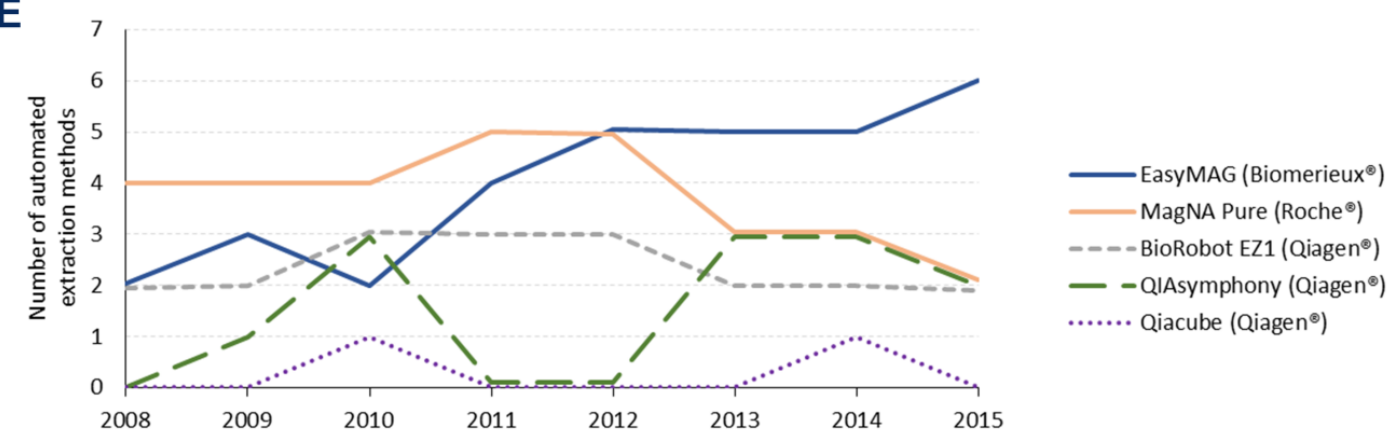

it essential to check the adequacy between the DNA extraction and the PCR method; the PCR assay in itself may not be well suited to a given extraction method (Sterkers et al., 2010a). Therefore, we cannot recommend an extraction method which would be best for any PCR assay. Yet, a few comparative studies (Faucher et al., 2012; Robert-Gangneux et al., 2017; Yera et al., 2009) provide some clues as to DNA extraction systems to be preferred or avoided specifically with the PCR assays tested.
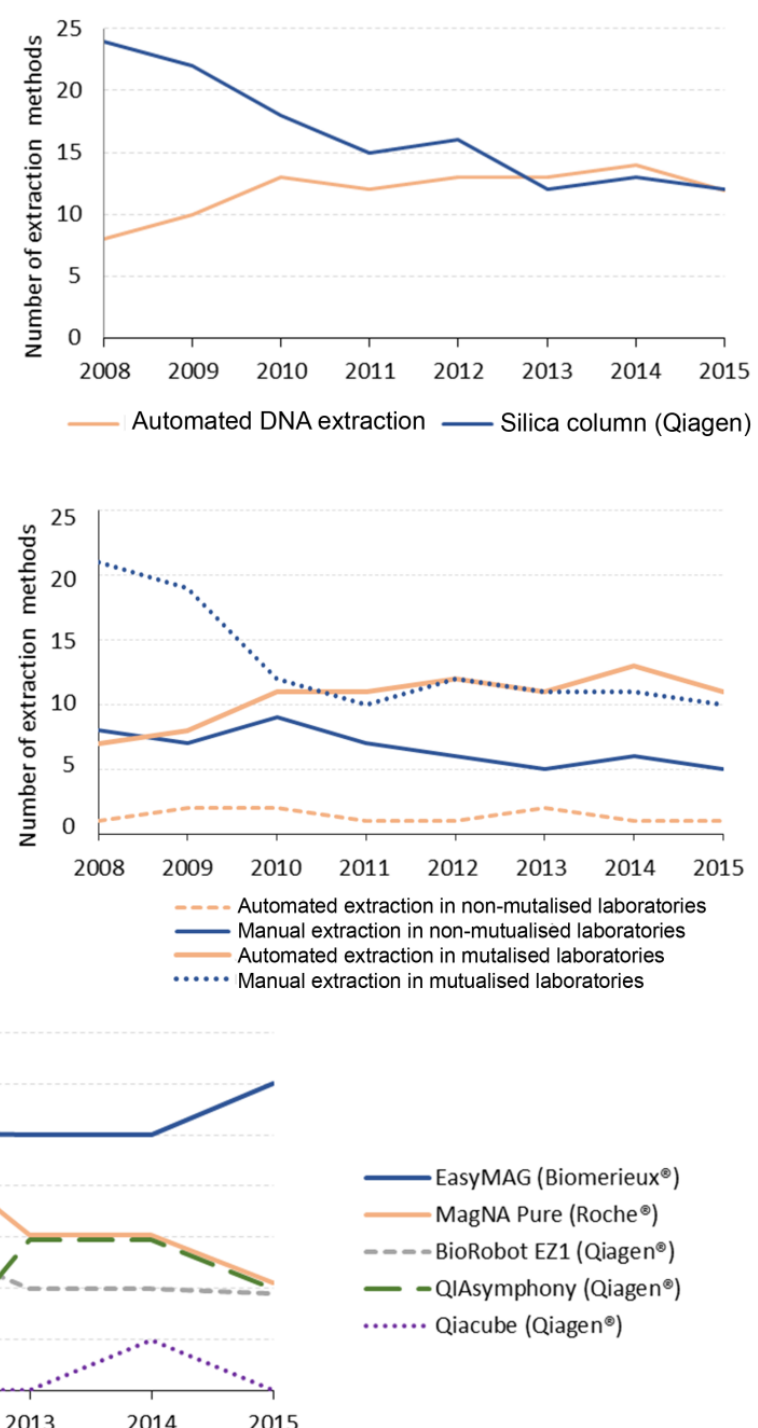

FIGURE 1: Evolution of DNA extraction methods in French laboratories performing Toxoplasma-PCR from 2008 to 2015.

A: Evolution of the number of laboratories using a second 'confirmation' PCR assay for molecular diagnosis of toxoplasmosis and using Qiagen ${ }^{\circledR}$ columns for DNA extraction. B: Parallel evolution of the number of methods using an automate and using Qiagen ${ }^{\circledR}$ columns for DNA extraction. C: Evolution of 
the automation of extraction methods. D: Parallel evolution of the automation of extraction methods in mutualized and non-mutualized laboratories. Mutualized laboratories are laboratories sharing their molecular biology equipment in a common platform for bacteriology, virology, parasitology and mycology. Non-mutualized laboratories are laboratories who did not share their molecular biology equipment for diagnosis of other infectious diseases. E: Evolution of the use of DNA extraction automates.

\subsubsection{PCR assays}

In total, 33 distinct PCR methods were reported during the whole period of the survey, differing from each other by the DNA target, primer sets and hybridizing probes; and 68 can be counted if one includes the thermal cycler device as a supplementary variation factor. Even more heterogeneity can be found if one considers more factors influencing assay performance such as the extraction method, the reaction mix etc. The major evolution observed here regarding PCR assays was the replacement of conventional PCR (cnPCR) by real-time PCR (qrtPCR) starting from 2012 (Figure 2.A and Table S1). This survey, was not designed to judge if the change from cnPCR to qrtPCR lead to improvements in diagnostic sensitivity. Yet, even if the better sensitivity of Toxoplasma qrtPCR compared to conventional PCR may be discussed (Bastien et al., 2008; Sterkers et al., 2010a), the use of qrtPCR is strongly supported by obvious mechanistic evidence of decreased risks of postamplification cross-contamination of samples, as well as robustness and speed of the technique. Overall, this appears as a positive change for the diagnosis of $T$. gondii in France, and we recommend using qrtPCR instead of cnPCR. The cost benefit of this change was not assessed in the survey; qPCR requires equipment and reagents which are more expensive than in cnPCR but saves technical time, making the final costs of both approaches equivalent in industrialized countries. In regions with limited resources, where labor costs are less, qrtPCR remains more expensive than cnPCR, impeding its access to a majority of laboratories.

\subsubsection{DNA targets}

Three DNA targets were used for Toxoplasma-PCR during the survey (Figure 2.B). The 'rep529' non-coding DNA sequence (accession number AF146527) was the most used DNA target during the whole period. This is supported by most comparative studies which demonstrated a better sensitivity when using 'rep529' than when using the B1 gene (Belaz et al., 2015; Cassaing et al., 2006; Menotti et al., 2010; Reischl et al., 2003; Sterkers et al., 2010a). The B1 gene target (accession number AF179871), which was reported in $11 / 37$ methods $(29.7 \%)$ in 2008 , dropped to $2 / 31$ methods $(6.5 \%)$ in 2014 and 1/27 method (3.7 \%) in 2015. One laboratory used the $18 \mathrm{~S}$ rDNA gene (accession number X75429) (Kupferschmidt et al., 2001) as PCR target, during the whole period. This point is the most consensual, we therefore recommend the use of the 'rep529' target. Of note, the suitability of this target for quantitation must be further assessed. 
A

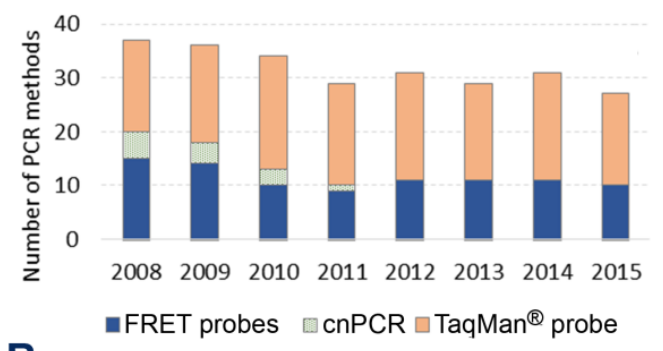

B

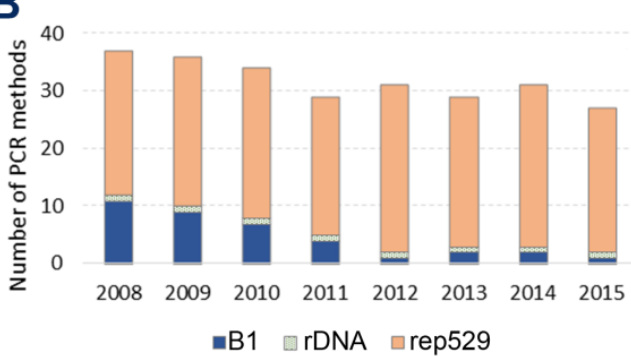

C

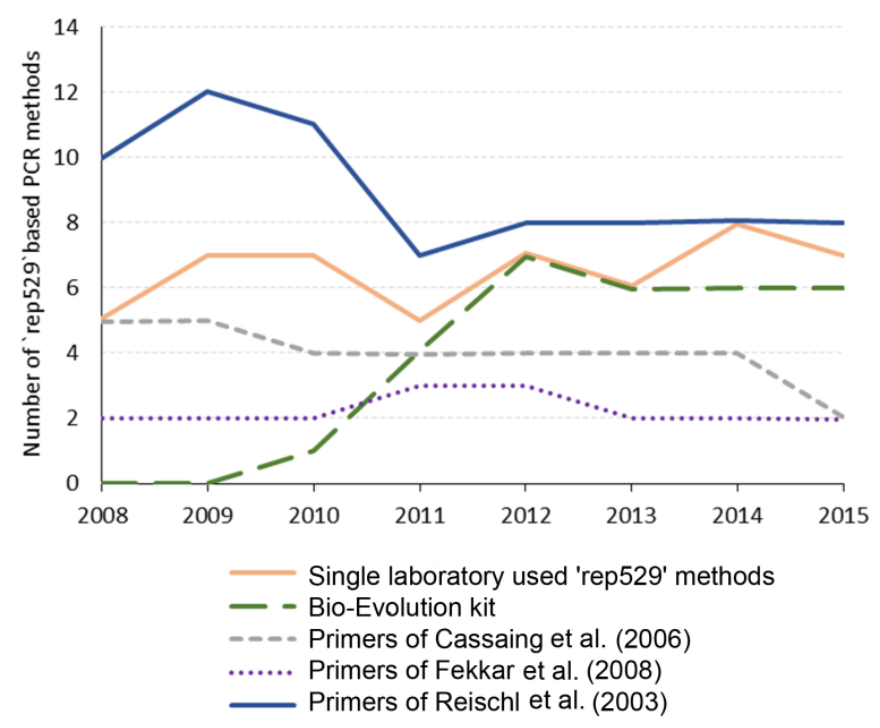

FIGURE 2: Evolution of PCR methods in French laboratories from 2008 to 2015.

A: Evolution of PCR product detection technologies of Toxoplasma-PCR. FRET probes: hybridization probes; TaqMan ${ }^{\circledR}$ probe: hydrolysis probe; cnPCR: conventional PCR. B: Evolution of the sequences targeted by Toxoplasma-PCR. B1: B1 gene (AF179871); rep529: 'rep529' non-coding DNA sequence (AF146527); rDNA: 18S rDNA gene (X75429). C: Evolution of the primer sets used in Toxoplasma-PCR targeting the 'rep529' sequence. "Single laboratory-used 'rep529' methods" are methods using primers used by only one participant. They comprised the TIB Molbiol Light Mix kit ${ }^{\circledR}$ and methods described in the following publications(Costa and Bretagne, 2012; Daval et al., 2010; Lélu et al., 2012; Menotti et al., 2010; Robert-Gangneux et al., 2010; Talabani et al., 2009; Wahab et al., 2010).

\subsubsection{PCR methods}

The DNA primers and probes appeared as the most variable parameters and greatest source of heterogeneity in the molecular diagnosis of toxoplasmosis: indeed, 17 and 13 different qrtPCR primer sets were being used in 2008 and 2015 respectively (for details, see Table S2). Due to this great heterogeneity, it is difficult to infer any recommendations. However, since 2011, the PCR method described by Reischl et al. (laboratory-developed FRET) and the BioEvolution ${ }^{\circledR}$ kit (TaqMan $\AA$ ) are the most widely used methods (Figure 2.C); both have been shown to be highly sensitive methods in previous studies (Filisetti et al., 2015; Reischl et al., 2003; Sterkers et al., 2010a; Varlet-Marie et al., 2014) and (Filisetti et al., 2015). The commercial Toxoplasma ELITe MGB kit (Elitech $\left.{ }^{\circledR}\right)$ appeared recently as a robust alternative to Bio-Evolution ${ }^{\circledR}$ (Robert-Gangneux et al., 2017), but its use has not spread in French laboratories yet. It is important to stress that there was further heterogeneity within the group of users of the 'Reischl method'; for example, whereas the method initially described by Reischl et al. used hybridization probes, four centers used a hydrolysis probe and even more, in 2008 and 2009, one center performed cnPCR using these primers (for details, see Table S2 and http://dx.doi.org/10.17632/zpjdkh4274.1). Almost all primer pairs used have been published (Table S2). As much as 5-8 of them were being used by only one center each year ("single laboratory used 'rep529' methods" in Figure 2.C). The persistence of such a diversity may be explained by the fact that most of them stem from laboratory-developed methods that have been published by this same laboratory several years ago. In any case, it constitutes a severe hindrance for comparative evaluations, thus impeding to assess the value of each of these methods. Although published primer pairs have 
usually gone through a comparison with one other method, laboratories should aim at using PCR primers and methods which have proven of value in robust multisite studies.

\subsubsection{PCR controls and good practices}

Practices consensually considered to ensure sensitivity and specificity of PCR assays were surveyed. These so called "good practices" were: (i) with respect to sensitivity, the number of PCR reaction tube(s) per clinical sample and the use of DNA extraction controls and PCR inhibition controls; (ii) with respect to specificity, the use of Uracil-DNA Glycosylase and contamination controls. Toxoplasma-PCR methods show persistent sensitivity limits in prenatal diagnosis (de Oliveira Azevedo et al., 2016). This lack of sensitivity could be explained by low parasitic loads in amniotic fluid (Costa et al., 2001) which would induce false negative results due to stochastic distribution of parasites in the sample. A simple way to reduce this stochastic effect is to perform the analysis in several reaction tubes ('multiplicate'). Previous studies have clearly shown the interest of increasing the number of reactions when getting close to the sensitivity threshold of the methods (Sterkers et al., 2010a; VarletMarie et al., 2014). The participants predominantly (15/27 in 2015) realized at least three PCR reactions per clinical sample during the whole period (Figure 3.A). Still, some centers realized only two $(11 / 27)$ or even one $(2 / 27)$ reactions per sample. We recommend the analysis of clinical samples in dupli- or better triplicate. The proportion of centers controlling the DNA extraction increased from 21/37 methods (56.8\%) in 2008 to $22 / 27$ methods $(81.5 \%)$ in 2015 (Figure 3.B). This is important as a failed extraction may induce false negative results and cannot be detected in the absence of a specific control. The use of commercial DNA extraction controls emerged during the survey and represented
7/27 methods (25.9\%) in 2015. This increasing use is probably linked to the handiness of these controls compared to 'laboratory-made' controls. Seven types of extraction control protocols were reported during the whole survey period (for details, see Table S3) without us being able to determine if some are best suited than others. Hence, we cannot recommend any but we support the use of an extraction control. PCR inhibition is a cause of false negative results in clinical samples (Buckwalter et al., 2014). PCR inhibition controls were more frequently used than extraction controls during the whole survey, in 35/37 (94.6\%) and 27/27 (100\%) PCR methods in 2008 and 2015, respectively (Figure 3.C). The methods for controlling PCR inhibition evolved during the survey. The addition of $T$. gondii genomic DNA in a supplementary reaction tube containing the patient's DNA ('semiinternal' control) was the most frequently used method in 2008, implemented in 15/37 (40.5 \%) PCR methods; but it decreased to $5 / 27(18.5 \%)$ methods in 2015. In contrast, commercial inhibition controls had become the most popular control methods in 2015, being used in 13/27 (48.1\%) methods. PCR inhibition caused by the same DNA extract may be highly variable depending on the PCR method (Chabbert et al., 2004; Huggett et al., 2008; Pionzio and McCord, 2014). Hence, we recommend using an inhibition control bearing the same primer sequences as the pathogen's DNA target. T. gondii genomic DNA addition seems best suited, but it specifically exposes to a risk of cross-contamination and false positive results. Internal chimeric competitive controls avoid this risk because the control is a modified DNA target detected by a specific probe. False positive results due to carry-over contamination remain an issue in qrtPCR (de Oliveira Azevedo et al., 2016). We report here that contamination controls were widely used by the participants, with a relative decrease in use from 2010 to 2012 (Figure 3.D). We also 
report a decreasing use of Uracil-DNA glycosylase probably due to its absence in the Bio-Evolution ${ }^{\circledR}$ kit. It is noteworthy that the Toxoplasma ELITe MGB® kit comprises Uracil-DNA glycosylase. We consider that the minimal measures to be implemented for any PCR setup are:
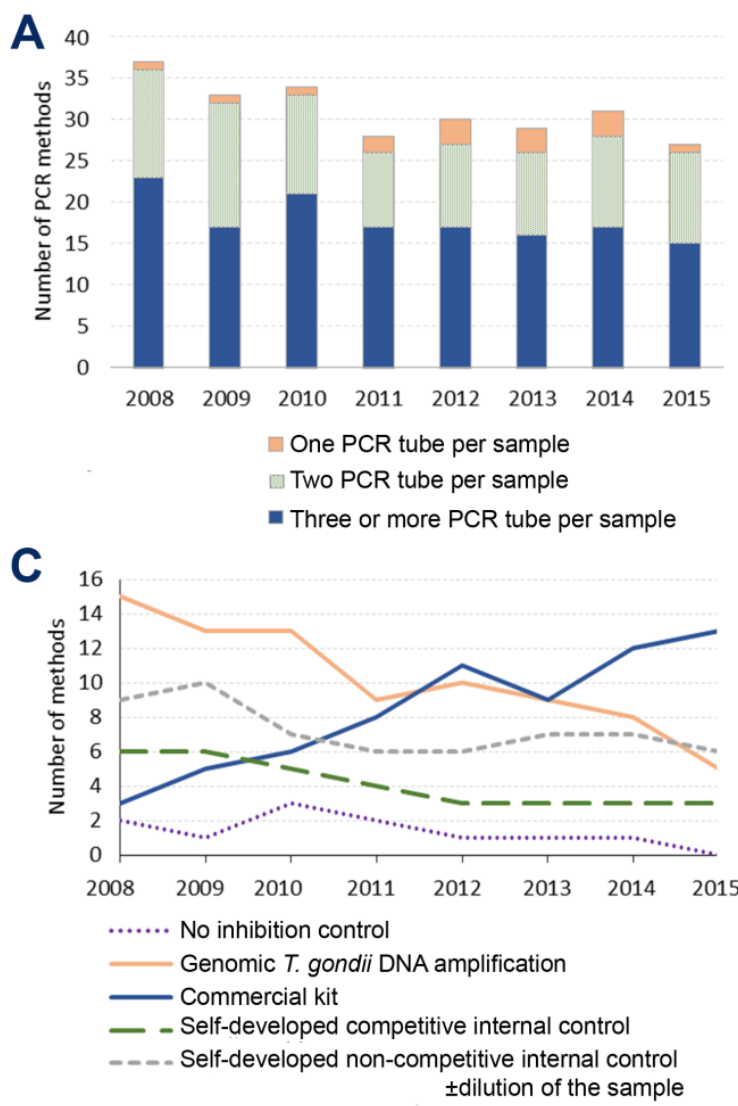

physical separation of DNA preparation, mix preparation and amplification rooms; respect of the flow from extraction to amplification; at least one (1-3) negative control reaction(s) in each PCR run; and the use of Uracil-DNA glycosylase.
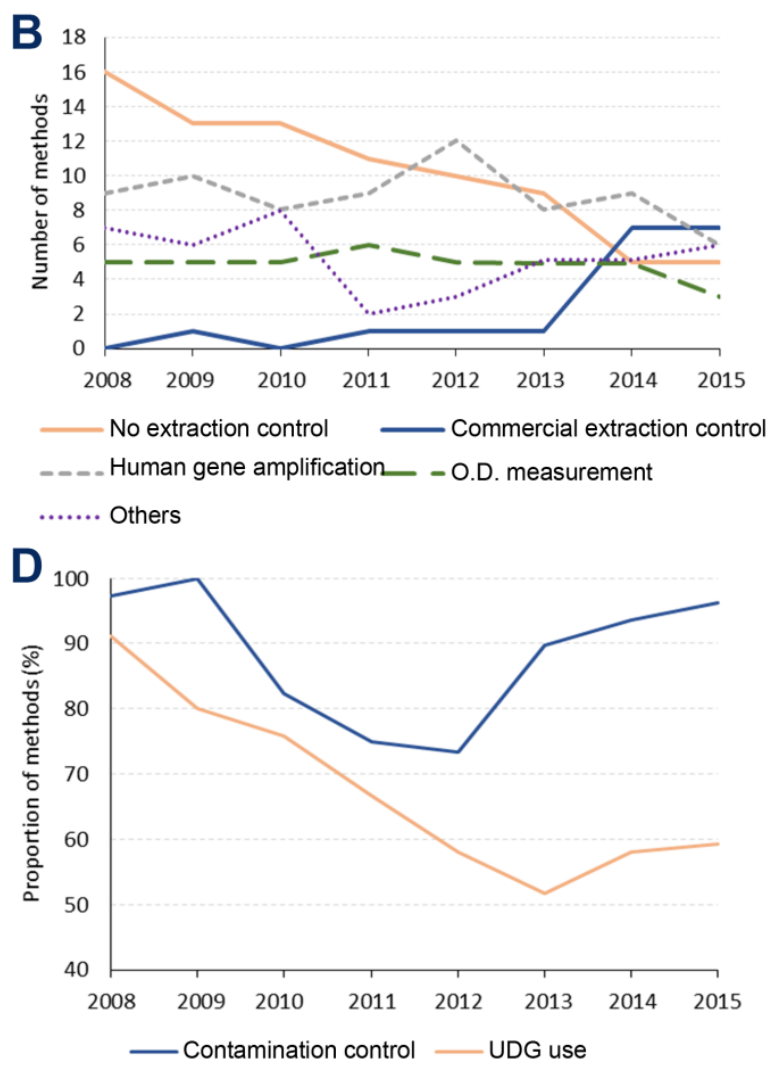

FIGURE 3: Evolution of good practices and control methods in molecular diagnosis of toxoplasmosis in French laboratories from 2008 to 2015.

A: Evolution of the number of PCR reaction tubes or wells per sample in the different PCR methods surveyed. B: Evolution of the extraction control methods used for Toxoplasma-PCR. Commercial DNA extraction controls comprised Diagenode, Eurogentec, MagNA Pure CMV, Simplexa, TIB Molbiol, TaqMan Rnase P Control reagent. "Human gene amplification" included PCR assays targeting albumin, betaglobin, Rnase (commercial kit not explicited by participant). Other methods comprised the use of a positive control in each extraction series, duplicate extraction using the same method, addition and amplification of mouse DNA, and the weekly amplification of GAPDH gene in six tubes. C: Evolution of the PCR inhibition control methods performed for Toxoplasma-PCR. "Commercial kit" comprised the inhibition controls included in the Bio-Evolution ${ }^{\circledR}$ kit, the TIB Molbiol® kit, or other commercial controls (Applied Biosystems®, Diagenode®, Simplexa®). A competitive internal control was a plasmid or oligonucleotide amplified by the same primers as ToxoplasmaPCR, but detected by a different probe. A non-competitive internal control was a plasmid, an oligonucleotide or genomic DNA amplified by primers different from those used for Toxoplasma-PCR. D: Evolution of the application of methods to ensure Toxoplasma-PCR specificity. Contamination controls consisted in an extra tube performed in each PCR run containing neither DNA extract nor Toxoplasma positive extract. UNG: Uracil DNA Glycosylase

The use of more PCR "good" practices was assessed only in the late versions of the questionnaire (http://dx.doi.org/10.17632/zpjdkh4274.1).
This included notably the method for determining cycles of positivity $(\mathrm{Cp})$ in qrtPCR, the systematic use of a positive control in each PCR run and the follow-up 
of its results using Levey-Jennings charts and "Westgard rules" (Westgard et al., 1981). It will be critical to explore these practices in future surveys in order to provide more ground for technical recommendations and help for the ISO 15189 certification of laboratories.

\section{Conclusion}

This study reports a nearly exhaustive panorama of Toxoplasma-PCR in the French clinical microbiology laboratories realizing this diagnosis and proposes technical guidelines for Toxoplasma-PCR. As congenital toxoplasmosis is particularly carefully handled and is the subject of a long term public health policy in France, this report reflects the evolution of practices in this molecular diagnosis in a subset of proficient laboratories. The diversity of methods and practices used for this diagnosis in French laboratories remained at a high level in 2008-2015 as compared with a previous similar survey from 2002-2005 (Sterkers et al., 2010b). The major changes between the two periods were (i) a progressive switch from cnPCR to qrtPCR, (ii) the complete abandonment of a second 'confirmation' PCR assay, (iii) the automation of DNA extraction and (iv) an almost universal switch to the 'rep529' DNA target. Two parameters may explain a persistent diversity: (i) most participants worked in a facility including other laboratories and had to make do with others for choosing the PCR device and extraction method; (ii) laboratories that have developed their own PCR method prefer not to change it. This high diversity of methods impairs robust performance comparisons between laboratories and impedes correct assessment of the value of infrequently used methods. The proposal of technical guidelines using previous published works and survey results may lead to reduce this diversity and to improve practices and performances.

\section{Acknowledgements}

We thank the members of the laboratories participating to the French National Quality Control of Toxoplasma-PCR for their annual answers to the questionnaire. We are grateful to S. Douzou, B. Sanichanh and G. Serres for their technical help. We acknowledge the financial support of the "RSI Caisse Assurance Maladie Professions Libérales Provinces, C.A.M.P.L.P." for buying the LightCycler 480 (Roche ${ }^{\circledR}$ ) real-time PCR equipment in Montpellier. Finally, this study received financial support from the French Ministry of Health (Institut de Veille Sanitaire/Santé Publique France).

\section{Conflicts of interest: none.}

\section{References}

Bastien, P., Jumas-Bilak, E., Varlet-Marie, E., Marty, P., ANOFEL Toxoplasma-PCR Quality Control Group, 2007. Three years of multi-laboratory external quality control for the molecular detection of Toxoplasma gondii in amniotic fluid in France. Clin. Microbiol. Infect. Off. Publ. Eur. Soc. Clin. Microbiol. Infect. Dis. 13, 430-433. https://doi.org/10.1111/j.1469-0691.2006.01642.x

Bastien, P., Procop, G.W., Reischl, U., 2008. Quantitative real-time PCR is not more sensitive than “conventional” PCR. J. Clin. Microbiol. 46, 18971900. https://doi.org/10.1128/JCM.02258-07

Belaz, S., Gangneux, J.-P., Dupretz, P., Guiguen, C., Robert-Gangneux, F., 2015. A 10-year retrospective comparison of two target sequences, REP-529 and B1, for Toxoplasma gondii detection by quantitative PCR. J. Clin. Microbiol. 53, 1294-1300. https://doi.org/10.1128/JCM.02900-14

Brenier-Pinchart, M.P., Morand-Bui, V., Fricker-Hidalgo, H., Equy, V., Marlu, R., Pelloux, H., 2007. Adapting a conventional PCR assay for Toxoplasma gondii detection to real-time quantitative PCR including a competitive internal control. Parasite Paris Fr. 14, 149-154.

Bretagne, S., Costa, J.M., Vidaud, M., Tran, J., Nhieu, V., Fleury-Feith, J., 1993. Detection of Toxoplasma gondii by competitive DNA amplification of bronchoalveolar lavage samples. J. Infect. Dis. 168, 1585-1588.

Buckwalter, S.P., Sloan, L.M., Cunningham, S.A., Espy, M.J., Uhl, J.R., Jones, M.F., Vetter, E.A., Mandrekar, J., Cockerill, F.R., Pritt, B.S., Patel, R., Wengenack, N.L., 2014. Inhibition controls for qualitative realtime PCR assays: are they necessary for all specimen matrices? J. Clin. Microbiol. 52, 2139-2143. https://doi.org/10.1128/JCM.03389-13

Cassaing, S., Bessières, M.H., Berry, A., Berrebi, A., Fabre, R., Magnaval, J.F., 2006. Comparison between two amplification sets for molecular diagnosis of toxoplasmosis by real-time PCR. J. Clin. Microbiol. 44, 720-724.

Chabbert, E., Lachaud, L., Crobu, L., Bastien, P., 2004. Comparison of two widely used PCR primer systems 
for detection of toxoplasma in amniotic fluid, blood, and tissues. J. Clin. Microbiol. 42, 1719-1722.

Costa, J.-M., Bretagne, S., 2012. Variation of B1 gene and AF146527 repeat element copy numbers according to Toxoplasma gondii strains assessed using real-time quantitative PCR. J. Clin. Microbiol. $50,1452-1454$.

Costa, J.M., Ernault, P., Gautier, E., Bretagne, S., 2001. Prenatal diagnosis of congenital toxoplasmosis by duplex real-time PCR using fluorescence resonance energy transfer hybridization probes. Prenat. Diagn. $21,85-88$.

Costa, J.M., Pautas, C., Ernault, P., Foulet, F., Cordonnier, C., Bretagne, S., 2000. Real-time PCR for diagnosis and follow-up of Toxoplasma reactivation after allogeneic stem cell transplantation using fluorescence resonance energy transfer hybridization probes. J. Clin. Microbiol. 38, 29292932.

Daval, S., Poirier, P., Armenaud, J., Cambon, M., Livrelli, V., 2010. Development of a real-time PCR assay for quantitative diagnosis of Toxoplasma gondii after allogeneic bone marrow transplantation. Pathol. Biol. (Paris) 58, 104-109.

de Oliveira Azevedo, C.T., do Brasil, P.E.A.A., Guida, L., Lopes Moreira, M.E., 2016. Performance of Polymerase Chain Reaction Analysis of the Amniotic Fluid of Pregnant Women for Diagnosis of Congenital Toxoplasmosis: A Systematic Review and Meta-Analysis. PloS One 11, e0149938. https://doi.org/10.1371/journal.pone.0149938

Faucher, B., Miermont, F., Ranque, S., Franck, J., Piarroux, R., 2012. Optimization of Toxoplasma gondii DNA extraction from amniotic fluid using NucliSENS easyMAG and comparison with QIAamp DNA minikit. Eur. J. Clin. Microbiol. Infect. Dis. 31, 1035-1039.

Fekkar, A., Bodaghi, B., Touafek, F., Le Hoang, P., Mazier, D., Paris, L., 2008. Comparison of immunoblotting, calculation of the GoldmannWitmer coefficient, and real-time PCR using aqueous humor samples for diagnosis of ocular toxoplasmosis. J. Clin. Microbiol. 46, 1965-1967.

Filisetti, D., Sterkers, Y., Brenier-Pinchart, M.-P., Cassaing, S., Dalle, F., Delhaes, L., Pelloux, H., Touafek, F., Varlet-Marie, E., Yera, H., Candolfi, E., Bastien, P., 2015. Multicentric comparative assessment of the bio-evolution Toxoplasma gondii detection kit with eight laboratory-developed PCR assays for molecular diagnosis of congenital toxoplasmosis. J. Clin. Microbiol. 53, 29-34.

Howick, J., Glasziou, P., Aronson, J.K., 2009. The evolution of evidence hierarchies: what can Bradford Hill's "guidelines for causation" contribute? J. R. Soc. Med. 102, 186-194. https://doi.org/10.1258/jrsm.2009.090020

Huggett, J.F., Novak, T., Garson, J.A., Green, C., MorrisJones, S.D., Miller, R.F., Zumla, A., 2008. Differential susceptibility of PCR reactions to inhibitors: an important and unrecognised phenomenon. BMC Res. Notes 1, 70. https://doi.org/10.1186/1756-0500-1-70

Kaiser, K., Van Loon, A.M., Pelloux, H., Ferrandiz, J., Picot, S., Wallace, P., Peyron, F., 2007. Multicenter proficiency study for detection of Toxoplasma gondii in amniotic fluid by nucleic acid amplification methods. Clin. Chim. Acta 375, 99-103.
Kupferschmidt, O., Krüger, D., Held, T.K., Ellerbrok, H., Siegert, W., Janitschke, K., 2001. Quantitative detection of Toxoplasma gondii DNA in human body fluids by TaqMan polymerase chain reaction. Clin. Microbiol. Infect. 7, 120-124.

Lélu, M., Villena, I., Dardé, M.-L., Aubert, D., Geers, R., Dupuis, E., Marnef, F., Poulle, M.-L., Gotteland, C., Dumètre, A., Gilot-Fromont, E., 2012. Quantitative estimation of the viability of Toxoplasma gondii oocysts in soil. Appl. Environ. Microbiol. 78, 51275132.

Lin, M.H., Chen, T.C., Kuo, T.T., Tseng, C.C., Tseng, C.P., 2000. Real-time PCR for quantitative detection of Toxoplasma gondii. J. Clin. Microbiol. 38, 41214125.

Menotti, J., Garin, Y.J.-F., Thulliez, P., Sérugue, M.-C., Stanislawiak, J., Ribaud, P., de Castro, N., Houzé, S., Derouin, F., 2010. Evaluation of a new 5'-nuclease real-time PCR assay targeting the Toxoplasma gondii AF146527 genomic repeat. Clin. Microbiol. Infect. $16,363-368$.

Pelloux, H., Weiss, J., Simon, J., Muet, F., FrickerHidalgo, H., Goullier-Fleuret, A., Ambroise-Thomas, P., 1996. A new set of primers for the detection of Toxoplasma gondii in amniotic fluid using polymerase chain reaction. FEMS Microbiol. Lett. $138,11-15$.

Pionzio, A.M., McCord, B.R., 2014. The effect of internal control sequence and length on the response to PCR inhibition in real-time PCR quantitation. Forensic Sci. Int. Genet. 9, 55-60.

Pomares, C., Montoya, J.G., 2016. Laboratory Diagnosis of Congenital Toxoplasmosis. J. Clin. Microbiol. 54, $2448-2454$.

Reischl, U., Bretagne, S., Krüger, D., Ernault, P., Costa, J.-M., 2003. Comparison of two DNA targets for the diagnosis of Toxoplasmosis by real-time PCR using fluorescence resonance energy transfer hybridization probes. BMC Infect. Dis. 3, 7.

Robert-Gangneux, F., Belaz, S., 2016. Molecular diagnosis of toxoplasmosis in immunocompromised patients. Curr. Opin. Infect. Dis. 29, 330-339.

Robert-Gangneux, F., Brenier-Pinchart, M.-P., Yera, H., Belaz, S., Varlet-Marie, E., Bastien, P., Molecular Biology Study Group of the French National Reference Center for Toxoplasmosis, 2017. Evaluation of Toxoplasma ELITe MGB Real-Time PCR Assay for Diagnosis of Toxoplasmosis. J. Clin. Microbiol. 55, 1369-1376.

Robert-Gangneux, F., Dupretz, P., Yvenou, C., Quinio, D., Poulain, P., Guiguen, C., Gangneux, J.-P., 2010. Clinical relevance of placenta examination for the diagnosis of congenital toxoplasmosis. Pediatr. Infect. Dis. J. 29, 33-38.

Sterkers, Y., Varlet-Marie, E., Cassaing, S., BrenierPinchart, M.P., Brun, S., Dalle, F., Delhaes, L., Filisetti, D., Pelloux, H., Yera, H., Bastien, P., 2010a. Multicentric comparative analytical performance study for molecular detection of low amounts of Toxoplasma gondii from simulated specimens. J. Clin. Microbiol. 48, 3216-3222.

Sterkers, Y., Varlet-Marie, E., Marty, P., Bastien, P., ANOFEL Toxoplasma-PCR Quality Control Group, 2010b. Diversity and evolution of methods and practices for the molecular diagnosis of congenital toxoplasmosis in France: a 4-year survey. Clin. Microbiol. Infect. 16, 1594-1602. 
Talabani, H., Asseraf, M., Yera, H., Delair, E., Ancelle, T., Thulliez, P., Brézin, A.P., Dupouy-Camet, J., 2009. Contributions of immunoblotting, real-time PCR, and the Goldmann-Witmer coefficient to diagnosis of atypical toxoplasmic retinochoroiditis. J. Clin. Microbiol. 47, 2131-2135.

Tomasoni, L.R., Meroni, V., Bonfanti, C., Bollani, L., Lanzarini, P., Frusca, T., Castelli, F., 2014. Multidisciplinary approach to congenital Toxoplasma infection: an Italian nationwide survey. New Microbiol. 37, 347-354.

Varlet-Marie, E., Sterkers, Y., Brenier-Pinchart, M.-P., Cassaing, S., Dalle, F., Delhaes, L., Filisetti, D., Pelloux, H., Touafek, F., Yera, H., Bastien, P., 2014. Characterization and multicentric validation of a common standard for Toxoplasma gondii detection using nucleic acid amplification assays. J. Clin. Microbiol. $\quad 52, \quad 3952-3959$. https://doi.org/10.1128/JCM.01906-14

Wahab, T., Edvinsson, B., Palm, D., Lindh, J., 2010. Comparison of the AF146527 and B1 repeated elements, two real-time PCR targets used for detection of Toxoplasma gondii. J. Clin. Microbiol. 48, 591-592.

Westgard, J.O., Barry, P.L., Hunt, M.R., Groth, T., 1981. A multi-rule Shewhart chart for quality control in clinical chemistry. Clin. Chem. 27, 493-501.

Yera, H., Filisetti, D., Bastien, P., Ancelle, T., Thulliez, P., Delhaes, L., 2009. Multicenter comparative evaluation of five commercial methods for Toxoplasma DNA extraction from amniotic fluid. J. Clin. Microbiol. 47, 3881-3886. 


\section{Supplementary tables}

\begin{tabular}{|c|c|c|c|c|c|c|c|c|c|c|c|c|c|c|c|c|c|c|}
\hline & \multicolumn{2}{|c|}{2008} & \multicolumn{2}{|c|}{2009} & \multicolumn{2}{|c|}{2010} & \multicolumn{2}{|c|}{2011} & \multicolumn{2}{|c|}{2012} & \multicolumn{2}{|c|}{2013} & \multicolumn{2}{|c|}{2014} & \multicolumn{2}{|c|}{2015} \\
\hline & & & $\mathbf{N}$ & $\%$ & $\mathbf{N}$ & $\%$ & $\mathbf{N}$ & $\%$ & $\mathbf{N}$ & $\%$ & $\mathbf{N}$ & $\%$ & $\mathbf{N}$ & $\%$ & $\mathbf{N}$ & $\%$ & $\mathbf{N}$ & $\%$ \\
\hline \multirow{3}{*}{\multicolumn{3}{|c|}{$\begin{array}{l}\text { Number of participating laboratories } \\
\text { Laboratories authorized for prenatal diagnosis } \\
\text { Number of methods }\end{array}$}} & 29 & & 28 & & 28 & & 26 & & 29 & & 28 & & 30 & & 26 & \\
\hline & & & 21 & 72.4 & 20 & 71.4 & 19 & 67.9 & 18 & 69.2 & 21 & 72.4 & 20 & 71.4 & 21 & 70.0 & 20 & 76.9 \\
\hline & & & 37 & & 36 & & 34 & & 29 & & 31 & & 29 & & 31 & & 27 & \\
\hline \multicolumn{3}{|c|}{$\begin{array}{l}\text { Number of laboratories using } 2 \text { different } \\
\text { methods }\end{array}$} & 8 & & 8 & & 6 & & 3 & & 2 & & 1 & & 1 & & 1 & \\
\hline \multicolumn{3}{|c|}{$N$ (laboratories using two different PCR methods) } & 6 & & 5 & & 4 & & 3 & & 2 & & 1 & & 1 & & 1 & \\
\hline \multicolumn{3}{|c|}{$N$ (labs using two different extraction methods) } & 1 & & 2 & & 0 & & 0 & & 0 & & 0 & & 0 & & 0 & \\
\hline \multicolumn{3}{|c|}{$N$ (laboratories using two different thermal cyclers) } & 1 & & 1 & & 2 & & 0 & & 0 & & 0 & & 0 & & 0 & \\
\hline \multirow{14}{*}{ c.o } & Number of $\mathrm{e}$ & xtraction methods used & 7 & & 8 & & 8 & & 6 & & 6 & & 7 & & 8 & & 6 & \\
\hline & Precipitatior & -based manual methods & 3 & 8.1 & 3 & 8.3 & 3 & 8.8 & 1 & 3.4 & 1 & 3.2 & 3 & 10.3 & 3 & 9.7 & 3 & 11.1 \\
\hline & & Tween-Nonidet-NaOH & 1 & 2.7 & 1 & 2.8 & 1 & 2.9 & 1 & 3.4 & 1 & 3.2 & 3 & 10.3 & 3 & 9.7 & 3 & 11.1 \\
\hline & Mast & er pure DNA purification (Epicentre ${ }^{\oplus}$ ) & 2 & 5.4 & 2 & 5.6 & 2 & 5.9 & 0 & 0.0 & 0 & 0.0 & 0 & 0.0 & 0 & 0.0 & 0 & 0.0 \\
\hline & Adsorption-I & pased manual methods & 26 & 70.3 & 23 & 63.9 & 18 & 52.9 & 16 & 55.2 & 17 & 54.8 & 13 & 44.8 & 14 & 45.2 & 12 & 44.4 \\
\hline & & Silica columns (Qiagen $\left.{ }^{\circledR}\right)^{a}$ & 24 & 64.9 & 22 & 61.1 & 18 & 52.9 & 15 & 51.7 & 16 & 51.6 & 12 & 41.4 & 13 & 41.9 & 12 & 44.4 \\
\hline & & High pure template (Roche ${ }^{\oplus}$ ) & 2 & 5.4 & 1 & 2.8 & 0 & 0.0 & 1 & 3.4 & 1 & 3.2 & 1 & 3.4 & 1 & 3.2 & 0 & 0.0 \\
\hline & $\begin{array}{l}\text { Automated } \\
\text { beads }\end{array}$ & extraction using magnetic & 8 & 21.6 & 10 & 27.8 & 12 & 35.3 & 12 & 41.4 & 13 & 41.9 & 13 & 44.8 & 13 & 41.9 & 12 & 44.4 \\
\hline & & BioRobot EZ1 (Qiagen $®)$ & 2 & 5.4 & 2 & 5.6 & 3 & 8.8 & 3 & 10.3 & 3 & 9.7 & 2 & 6.9 & 2 & 6.5 & 2 & 7.4 \\
\hline & & EasyMAG (Biomérieux $®)$ & 2 & 5.4 & 3 & 8.3 & 2 & 5.9 & 4 & 13.8 & 5 & 16.1 & 5 & 17.2 & 5 & 16.1 & 6 & 22.2 \\
\hline & & MagNA Pure (Roche $\left.{ }^{\circledR}\right)$ & 4 & 10.8 & 4 & 11.1 & 4 & 11.8 & 5 & 17.2 & 5 & 16.1 & 3 & 10.3 & 3 & 9.7 & 2 & 7.4 \\
\hline & & QIAsymphony (Qiagen $®)$ & 0 & 0.0 & 1 & 2.8 & 3 & 8.8 & 0 & 0.0 & 0 & 0.0 & 3 & 10.3 & 3 & 9.7 & 2 & 7.4 \\
\hline & Automated ext & raction using silica membrane & $\mathbf{0}$ & 0.0 & $\mathbf{0}$ & 0.0 & 1 & 2.9 & $\mathbf{0}$ & 0.0 & $\mathbf{0}$ & 0.0 & $\mathbf{0}$ & 0.0 & 1 & 3.2 & $\mathbf{0}$ & 0.0 \\
\hline & & Qiacube (Qiagen $\left.{ }^{\oplus}\right)$ & 0 & 0.0 & 0 & 0.0 & 1 & 2.9 & 0 & 0.0 & 0 & 0.0 & 0 & 0.0 & 1 & 3.2 & 0 & 0.0 \\
\hline
\end{tabular}




\begin{tabular}{|c|c|c|c|c|c|c|c|c|c|c|c|c|c|c|c|c|c|c|}
\hline \multirow{9}{*}{ 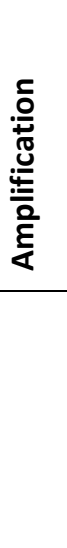 } & $\mathbf{q P C R}^{\mathrm{b}}$ & & 32 & 86.5 & 32 & 88.9 & 31 & 91.2 & 28 & 96.6 & 31 & 100.0 & 29 & 100.0 & 31 & 100.0 & 27 & 100.0 \\
\hline & & Hybridization probes & 15 & 40.5 & 14 & 38.9 & 10 & 29.4 & 9 & 31.0 & 11 & 35.5 & 11 & 37.9 & 11 & 35.5 & 10 & 37.0 \\
\hline & & Hydrolysis probe & 17 & 45.9 & 18 & 50.0 & 21 & 61.8 & 19 & 65.5 & 20 & 64.5 & 18 & 62.1 & 20 & 64.5 & 17 & 63.0 \\
\hline & $\mathrm{CnPCR}^{\mathrm{c}}$ & & 5 & 13.5 & 4 & 11.1 & 3 & 8.8 & 1 & 3.4 & 0 & 0.0 & 0 & 0.0 & 0 & 0.0 & 0 & 0.0 \\
\hline & Number & (s) per PCR & & & & & & & & & & & & & & & & \\
\hline & & 1 & 1 & 2.7 & 1 & 2.8 & 1 & 2.9 & 2 & 6.9 & 3 & 9.7 & 3 & 10.3 & 3 & 9.7 & 1 & 3.7 \\
\hline & & 2 & 13 & 35.1 & 15 & 41.7 & 12 & 35.3 & 9 & 31.0 & 10 & 32.3 & 10 & 34.5 & 11 & 35.5 & 11 & 40.7 \\
\hline & & 3 or more & 23 & 62.2 & 17 & 47.2 & 21 & 61.8 & 17 & 58.6 & 17 & 54.8 & 16 & 55.2 & 17 & 54.8 & 15 & 55.6 \\
\hline & & not specified & 0 & 0.0 & 3 & 8.3 & 0 & 0.0 & 1 & 3.4 & 1 & 3.2 & 0 & 0.0 & 0 & 0.0 & 0 & 0.0 \\
\hline
\end{tabular}

Table S1: Evolution of general practices in molecular diagnosis of toxoplasmosis in French laboratories from 2008 to 2015

${ }^{a}$ Qiagen ${ }^{\circledR}$ silica columns extraction methods corresponded to 31 QIAamp DNA Minikit, seven QIAamp DNA Blood Minikit, two QIAprep

Miniprep, one DNeasy Blood \& Tissue and 96 Qiagen columns without additional precision; ${ }^{\mathrm{b}}$ real-time PCR; ${ }^{\mathrm{c}}$ conventional PCR 
Table S2: Evolution of DNA targets, primer sets and probe types used in molecular diagnosis of toxoplasmosis in French laboratories from 2008 to 2015

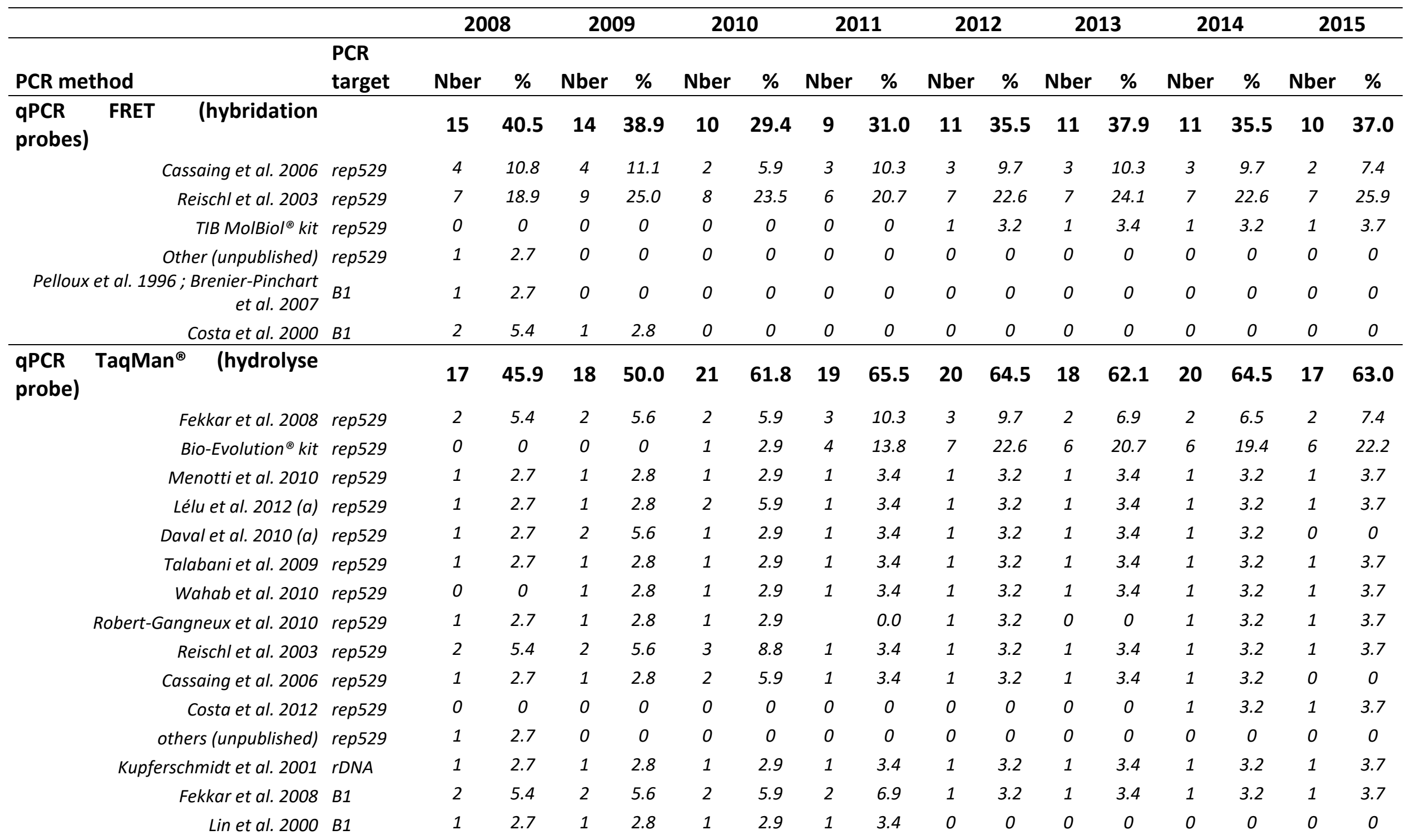




\begin{tabular}{|c|c|c|c|c|c|c|c|c|c|c|c|c|c|c|c|c|c|c|}
\hline & Bretagne et al. 1993 & $B 1$ & 1 & 2.7 & 1 & 2.8 & 1 & 2.9 & 1 & 3.4 & 0 & 0 & 0 & 0 & 0 & 0 & 0 & 0 \\
\hline & others (unpublished) & B1 & 1 & 2.7 & 1 & 2.8 & 1 & 2.9 & 0 & 0 & 0 & 0 & 1 & 3.4 & 1 & 3.2 & 0 & 0 \\
\hline CnPCR & & & 5 & 13.5 & 4 & 11.1 & 3 & 8.8 & 1 & 3.4 & 0 & 0 & 0 & 0 & 0 & 0 & 0 & 0 \\
\hline Total & & & 37 & 100 & 36 & 100 & 34 & 100 & 29 & 100 & 31 & 100 & 29 & 100 & 31 & 100 & 27 & 100 \\
\hline
\end{tabular}

a: Techniques used twice by the same laboratory with different extraction methods in 2010 for Lélu et al. And in 2009 for Daval et al. respectively

\section{Table S2: Evolution of DNA targets, primers sets and probe types used in molecular diagnosis of toxoplasmosis in French}

\section{laboratories from 2008 to 2015}

* Techniques used twice by the same laboratory with different extraction methods in 2010 for Lélu et al. and in 2009 for Daval et al. respectively

Brenier-Pinchart, M.P., Morand-Bui, V., Fricker-Hidalgo, H., Equy, V., Marlu, R., Pelloux, H., 2007. Adapting a conventional PCR assay for Toxoplasma gondii detection to real-time quantitative PCR including a competitive internal control. Parasite Paris Fr. 14, 149-154.

Bretagne, S., Costa, J.M., Vidaud, M., Tran, J., Nhieu, V., Fleury-Feith, J., 1993. Detection of Toxoplasma gondii by competitive DNA amplification of bronchoalveolar lavage samples. J. Infect. Dis. $168,1585-1588$

Cassaing, S., Bessières, M.H., Berry, A., Berrebi, A., Fabre, R., Magnaval, J.F., 2006. Comparison between two amplification sets for molecular diagnosis of toxoplasmosis by real-time PCR. J. Clin. Microbiol. 44, 720-724.

Costa, J.-M., Bretagne, S., 2012. Variation of B1 gene and AF146527 repeat element copy numbers according to Toxoplasma gondii strains assessed using real-time quantitative PCR. J. Clin. Microbiol. 50, 1452-1454.

Costa, J.M., Pautas, C., Ernault, P., Foulet, F., Cordonnier, C., Bretagne, S., 2000. Real-time PCR for diagnosis and follow-up of Toxoplasma reactivation after allogeneic stem cell transplantation using fluorescence resonance energy transfer hybridization probes. J. Clin. Microbiol. 38, 2929-2932.

Daval, S., Poirier, P., Armenaud, J., Cambon, M., Livrelli, V., 2010. Development of a real-time PCR assay for quantitative diagnosis of Toxoplasma gondii after allogeneic bone marrow transplantation. Pathol. Biol. (Paris) 58, 104-109.

Fekkar, A., Bodaghi, B., Touafek, F., Le Hoang, P., Mazier, D., Paris, L., 2008. Comparison of immunoblotting, calculation of the Goldmann-Witmer coefficient, and real-time PCR using aqueous humor samples for diagnosis of ocular toxoplasmosis. J. Clin. Microbiol. 46, 1965-1967.

Kupferschmidt, O., Krüger, D., Held, T.K., Ellerbrok, H., Siegert, W., Janitschke, K., 2001. Quantitative detection of Toxoplasma gondii DNA in human body fluids by TaqMan polymerase chain reaction. Clin. Microbiol. Infect. 7, 120-124.

Lélu, M., Villena, I., Dardé, M.-L., Aubert, D., Geers, R., Dupuis, E., Marnef, F., Poulle, M.-L., Gotteland, C., Dumètre, A., Gilot-Fromont, E., 2012. Quantitative estimation of the viability of Toxoplasma gondii oocysts in soil. Appl. Environ. Microbiol. 78, 5127-5132.

Lin, M.H., Chen, T.C., Kuo, T.T., Tseng, C.C., Tseng, C.P., 2000. Real-time PCR for quantitative detection of Toxoplasma gondii. J. Clin. Microbiol. 38, $4121-4125$.

Menotti, J., Garin, Y.J.-F., Thulliez, P., Sérugue, M.-C., Stanislawiak, J., Ribaud, P., de Castro, N., Houzé, S., Derouin, F., 2010. Evaluation of a new 5'-nuclease real-time PCR assay targeting the Toxoplasma gondii AF146527 genomic repeat. Clin. Microbiol. Infect. 16, 363-368.

Pelloux, H., Weiss, J., Simon, J., Muet, F., Fricker-Hidalgo, H., Goullier-Fleuret, A., Ambroise-Thomas, P., 1996. A new set of primers for the detection of Toxoplasma gondii in amniotic fluid using polymerase chain reaction. FEMS Microbiol. Lett. 138, 11-15.

Reischl, U., Bretagne, S., Krüger, D., Ernault, P., Costa, J.-M., 2003. Comparison of two DNA targets for the diagnosis of Toxoplasmosis by real-time PCR using fluorescence resonance energy transfer hybridization probes. BMC Infect. Dis. 3, 7.

Robert-Gangneux, F., Dupretz, P., Yvenou, C., Quinio, D., Poulain, P., Guiguen, C., Gangneux, J.-P., 2010. Clinical relevance of placenta examination for the diagnosis of congenital toxoplasmosis. Pediatr. Infect. Dis. J. 29, 33-38.

Talabani, H., Asseraf, M., Yera, H., Delair, E., Ancelle, T., Thulliez, P., Brézin, A.P., Dupouy-Camet, J., 2009. Contributions of immunoblotting, real-time PCR, and the Goldmann-Witmer coefficient to diagnosis of atypical toxoplasmic retinochoroiditis. J. Clin. Microbiol. 47, 2131-2135.

Wahab, T., Edvinsson, B., Palm, D., Lindh, J., 2010. Comparison of the AF146527 and B1 repeated elements, two real-time PCR targets used for detection of Toxoplasma gondii. J. Clin. Microbiol. 48, 591-592. 


\begin{tabular}{|c|c|c|c|c|c|c|c|c|}
\hline & & & & & & & & \\
\hline & 2008 & 2009 & 2010 & 2011 & 2012 & 2013 & 2014 & 2015 \\
\hline Extraction control method & 21 & 22 & 22 & 16 & 23 & 21 & 24 & 23 \\
\hline Repeated extraction using the same method & 1 & 1 & 8 & 1 & 4 & 6 & 3 & 3 \\
\hline Optical Density measurement & 5 & 5 & 5 & 7 & 6 & 6 & 5 & 4 \\
\hline Human gene amplification & 9 & 10 & 9 & 6 & 12 & 8 & 9 & 9 \\
\hline Mouse DNA addition & 0 & 0 & 0 & 0 & 0 & 0 & 1 & 1 \\
\hline Weekly amplifications of a house keeping gene & 0 & 0 & 0 & 0 & 0 & 0 & 0 & 0 \\
\hline Use of a positive/negative control & 6 & 5 & 0 & 0 & 0 & 0 & 1 & 1 \\
\hline Commercial extraction control ${ }^{a}$ & 0 & 1 & & 1 & 1 & 1 & 5 & 5 \\
\hline None & 16 & 13 & 13 & 11 & 7 & 8 & 6 & 5 \\
\hline Inhibition control method & 32 & 33 & 32 & 25 & 18 & 28 & 29 & 29 \\
\hline Genomic T. gondii DNA amplification & 12 & 11 & 12 & 10 & 9 & 9 & 8 & 6 \\
\hline Human gene amplification & 4 & 4 & 3 & 2 & 2 & 2 & 2 & 3 \\
\hline Non competitive exogenous DNA amplification ${ }^{b}$ & 4 & 3 & 4 & 3 & 3 & 4 & 5 & 5 \\
\hline Competitive internal control $^{c}$ & 4 & 6 & 5 & 4 & 3 & 3 & 3 & 3 \\
\hline Internal control and $1 / 5$ dilution of the sample & 2 & 2 & 1 & 1 & 1 & 1 & 0 & 0 \\
\hline Positive sample & 3 & 2 & 1 & 0 & 0 & 0 & 0 & 0 \\
\hline Commercial kit ${ }^{d}$ & 3 & 5 & 6 & 5 & $12^{e}$ & 9 & 11 & 12 \\
\hline None & 3 & 1 & 3 & 2 & 1 & 1 & 1 & 0 \\
\hline Use of a contamination control (per laboratory) & $28 / 29$ & $27 / 28$ & $23 / 28$ & $18 / 24$ & $21 / 29$ & $26 / 29$ & $27 / 30$ & $28 / 29$ \\
\hline \multicolumn{9}{|l|}{ Use of Uracil-DNA glycosylase (per laboratory) } \\
\hline No & 3 & 4 & 6 & 6 & 12 & 14 & 13 & 12 \\
\hline Yes & 25 & 24 & 22 & 17 & 17 & 15 & 17 & 17 \\
\hline Not preciseds & 1 & 0 & 0 & 1 & 0 & 0 & 0 & 0 \\
\hline
\end{tabular}

\section{TABLE S3: Evolution of control methods of molecular diagnosis of toxoplasmosis in French laboratories from 2008 to 2015}

${ }^{a}$ Commercial controls comprised Diagenode, Eurogentec, MagNaPure CMV, Simplexa, Tib MolBiol. ${ }^{b}$ Amplification of a murine sequence or a plasmid or phage sequence. ${ }^{c}$ Amplification of a plasmid or an oligonucleotide using the same primers than Toxoplasma-PCR. ${ }^{d}$ Use of controls

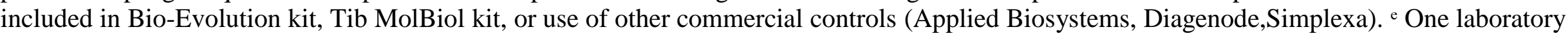
used two different inhibition control methods 